\title{
Antiviral Drugs from the Nucleoside Analog Family Block Volume- Activated Chloride Channels
}

\author{
Martin Gschwentner,* Alex Susanna,* Ewald Wöll, ${ }^{+}$ \\ Markus Ritter, ${ }^{\dagger}$ Ulrich O. Nagl,* Andreas Schmarda,* \\ Andreas Laich, * Germar M. Pinggera, * Helmut Ellemunter, ${ }^{*}$ \\ Hartwig Huemer, \$ Peter Deetjen,* and Markus Paulmichl* \\ *Department of Physiology, 'Department of Internal Medicine, \\ ${ }^{\ddagger}$ Department of Pediatrics, and ${ }^{\S}$ Department of Hygiene, University of \\ Innsbruck, Innsbruck, Austria
}

\begin{abstract}
Background: The antiviral drugs AZT and acyclovir are generally used in the treatment of infections with human immunodeficiency virus (HIV) and herpes simplex virus (HSV). These substances are known to impede virus replication by premature nucleic acid chain termination. It is not yet clear, however, if this is the sole mechanism responsible for the antiviral and/or the numerous side effects observed in patients treated with these agents. We investigated the swelling-induced chloride current in fibroblasts, which we demonstrated is closely related or identical to a cloned epithelial chloride channel, $\mathrm{I}_{\mathrm{Cln}}$. This chloride channel can be blocked by nucleotides.

Materials and Methods: Electrophysiological, fluorescence optical, and volume measurements were made to determine the effect of nucleoside analogs on the swell-
\end{abstract}

ing-dependent chloride current $\left(\mathrm{I}_{\mathrm{Cl}}\right)$ in $\mathrm{NIH}$ 3T3 fibroblasts and in human $\mathrm{T}$ cell lymphoma (H9) cells and the cAMP-dependent chloride current in CaCo cells.

Results: AZT and acyclovir block the swelling-dependent chloride current and the chloride flux in fibroblasts, and the regulatory volume decrease (RVD) and $\mathrm{I}_{\mathrm{Cl}}$ in $\mathrm{H} 9$ cells. This immediate effect can be substantially reduced by the simultaneous incubation of the cells with thymidine-5'-diphosphate (TDP) or uridine, both of which are by themselves unable to affect $\mathrm{I}_{\mathrm{Cl}}$.

Conclusions: We show here a novel molecular mechanism by which antiviral drugs of the nucleoside analog family could lead to impairments of the kidney, bone marrow, gastrointestinal, and neuronal functions, and how these side effects could possibly be restricted by the presence of TDP or uridine.

\section{INTRODUCTION}

The use of nucleoside analogs is a major strategy in the treatment of viral infections. The key mechanism by which these substances interfere with virus replication appears to be by inducing premature chain termination; it is still unclear, however, if this is the exclusive antiviral effect and how different side effects observed both in vitro and in patients treated with these drugs can be explained. The side effects consist mainly of

Correspondence address and reprint requests to: Markus Paulmichl, Department of Physiology, University of Innsbruck, Fritz-Pregl-Strasse 3, A-6020 Innsbruck, Austria. bone marrow suppression and impaired central and peripheral neuronal tissue, gastrointestinal tissue, and kidney function. This organ preference for the side effects of these drugs seems to result from mechanisms different from premature chain termination. As previously demonstrated, $\mathrm{I}_{\mathrm{Cln}}$, a chloride channel cloned from epithelial cells and expressed in Xenopus laevis oocytes, can be blocked by the addition of different nucleotides (cGMP, ITP, cAMP, GTP, ATP, ADP, or AMP) to the extracellular solution (1). A similar nucleotide block of chloride currents has recently been shown in other cell systems (2-4). Mutation of a putative nucleotide binding region in $\mathrm{I}_{\mathrm{Cln}}$ leads to a dramatic reduction of the nu- 
cleotide block and to a change in the kinetics of the current expressed in oocytes (1). In NIH 3T3 fibroblasts, the swelling-induced chloride current $\left(\mathrm{I}_{\mathrm{Cl}}\right)$ can similarly be blocked by cAMP, cGMP, or ATP. This endogenous current can be significantly reduced by antisense oligonucleotides against $\mathrm{I}_{\mathrm{Cln}}$, indicating that $\mathrm{I}_{\mathrm{Cln}}$ is the prevalent protein involved in $\mathrm{I}_{\mathrm{Cl}}(5)$. The aim of the present study was to investigate the effect of antiviral drugs from the nucleoside analog family on $\mathrm{I}_{\mathrm{Cl}}$. We show here that nucleoside analogs selectively block $\mathrm{I}_{\mathrm{Cl}}$ and the regulatory volume decrease (RVD) at concentrations one to two orders of magnitude lower than nucleotides, thus interfering with a vital cell regulatory mechanism at concentrations present in the plasma of patients treated with these drugs.

\section{MATERIAL AND METHODS}

\section{Electrophysiology and Cell Culture}

The whole-cell voltage clamp method (6) was chosen to measure swelling-induced chloride currents in isolated NIH 3T3 fibroblasts, colon carcinoma ( $\mathrm{CaCo}$ ) cells, and $\mathrm{H} 9$ cells, a human $\mathrm{T}$ cell lymphoma cell line (ATCC HTB 176). Fibroblasts and CaCo cells were grown on glass cover slips in Dulbecco's modified Eagle's medium (DMEM) supplemented with $10 \%$ fetal calf serum, $4 \mathrm{mM}$ glutamine, $100 \mathrm{IU} / \mathrm{ml}$ penicillin, 100 $\mu \mathrm{g} / \mathrm{ml}$ streptomycin at $37^{\circ} \mathrm{C}, 5 \% \mathrm{CO}_{2}, 95 \%$ air, and measured 24-48 hr after splitting. H9 cells were grown in suspension in RPMI-1640 medium supplemented with $10 \%$ fetal calf serum, 2 $\mathrm{mM}$ glutamine, $100 \mathrm{IU} / \mathrm{ml}$ penicillin, $100 \mu \mathrm{g} / \mathrm{ml}$ streptomycin at $37^{\circ} \mathrm{C}, 5 \% \mathrm{CO}_{2}, 95 \%$ air. For electrical measurements in $\mathrm{H} 9$ cells, glass cover slips were coated with a $0.25 \%$ collagen solution (type I). All experiments were carried out at room temperature $\left(20-22^{\circ} \mathrm{C}\right)$. Bath and pipette solutions were chosen to enable chloride current measurements. The isotonic extracellular solution used was composed of (in $\mathrm{mM}$ ): $\mathrm{NaCl} \mathrm{125,}$ $\mathrm{CaCl}_{2}$ 2.5, $\mathrm{MgCl}_{2}$ 2.5, N-2-hydroxyethylpiperazine-N'-2-ethanesulfonic acid (HEPES) 10, mannitol 50, pH 7.2 (adjusted with $\mathrm{NaOH}$ ). Mannitol was omitted to reduce extracellular osmolarity. One to two minutes after confirming whole-cell configuration, hypotonic conditions were established and the activated outwardly rectifying chloride current measured. Fast exchange of the bath solution was obtained using a perfusion system with a flow rate of $10 \mathrm{ml} / \mathrm{min}$ and a bath volume of $\approx 250 \mu$ l. The blocking effect on $\mathrm{I}_{\mathrm{Cl}}$ of the different substances tested was determined 2-4 min after the addition of the corresponding concentrations to the extracellular solution. The filling solution of the patch pipette was (in $\mathrm{mM}$ ): $\mathrm{CsCl} 144, \mathrm{MgCl}_{2}$ 5, ethyleneglycol-bis ( $\beta$-aminoethyl ether)-N,N, $\mathrm{N}^{\prime}, \mathrm{N}^{\prime}$-tetraacetic acid (EGTA) 11, HEPES 10, pH 7.2 (adjusted with $\mathrm{CsOH}$ ). For data acquisition and analysis an EPC-9 (HEKA, Lambrecht, Germany) and an Axopatch 200A (Axon Instruments, Foster City, CA U.S.A.) amplifier, controlled by an Atari or an Apple computer running the according software for driving the amplifier and PULSE and REVIEW for analysis (Instrutech, Great Neck, NY U.S.A.) was used. All current measurements were filtered at $1 \mathrm{kHz}$ (analog 4-pole BESSEL) and leak subtracted where indicated. Where applicable, data are expressed as arithmetic means \pm standard error of the mean (SEM). Statistical analysis was made by $t$-test where appropriate. Significant difference was assumed at $p<0.05$.

\section{Fluorescence Optical Measurements}

CHLORIDE MEASUREMENTS USING MEQ. NIH $3 \mathrm{~T} 3 \mathrm{fi}-$ broblasts were superfused with a hypotonic solution containing (in $\mathrm{mM}$ ): Na-gluconate $81, \mathrm{~K}$ gluconate 5.4, $\mathrm{MgSO}_{4}$ 0.8, Ca-gluconate 1.2, $\mathrm{NaH}_{2} \mathrm{PO}_{4}$ 1, glucose 5.5, Tris(hydroxymethyl) aminomethane (Tris) 5, pH adjusted to 7.4. At the point indicated (arrow in Fig. 1d), the hypotonic extracellular fluid was changed to a solution containing $150 \mathrm{mM} \mathrm{KSCN}$. The decrease of fluorescence is proportional to chloride permeability $\left(\mathrm{P}_{\mathrm{Cl}}\right)$ since $\mathrm{SCN}^{-}$is able to quench MEQ (6-methoxy-N-ethylquinolinium iodide) fluorescence more effectively than chloride (7), $\mathrm{I}_{\mathrm{Cln}}$ is more permeable for $\mathrm{SCN}^{-}$than for chloride (8), and $\mathrm{I}_{\mathrm{Cl}}$ is reduced by only $\approx 40 \%$ within the first $180 \mathrm{sec}$ after restoring normal osmolarity. Fluorescence measurements were made under an inverted microscope equipped for epifluorescence and photometry. Light from a xenon arc lamp was directed through a grey filter (nominal transmission $0.3 \%$ ) and a $340 \pm 10 \mathrm{~nm}$ interference filter, deflected by a dichroic mirror and directed through the objective. The emitted light was directed through a $420 \mathrm{~nm}$ cutoff filter to a cooled photomultiplier tube for photon counting (9). For loading the cells with MEQ it is essential to convert MEQ to diH-MEQ (6-methoxy-Nethyl 1,2-dihydroquinolinium iodide; methods are described in Ref. 10). The fibroblasts were 
incubated for 10 minutes in a $5-\mu \mathrm{M}$ diH-MEQ solution $\left(37^{\circ} \mathrm{C}, 5 \% \mathrm{CO}_{2}\right)$, washed with PBS and incubated in DMEM for another $10 \mathrm{~min}$ prior to measurement.

VIABILITY MEASUREMENTS. Viability of NIH 3 T3 fibroblasts was measured using a confocal microscope (LSM 410, Zeiss, Oberkochen, Germany) after labeling the cells with calcein $\mathrm{AM}$ and ethidium homodimer (11). Cells were grown on sterile glass cover slips (see above) and incubated for 20 min with $2 \mu \mathrm{M}$ calcein $\mathrm{AM}$ and $4 \mu \mathrm{M}$ ethidium homodimer as described by the supplier (EucoLight, Molecular Probes, Eugene, OR, U.S.A.). After washing the cells with PBS the cover slips were mounted under an inverted laser scan microscope (LSM 410). The fluorescent dyes were excited by an argon laser $(488 \mathrm{~nm})$. Fluorescence emission from both fluorophores was viewed simultaneously using a dichroic mirror (FT580) and two emission filters $(530 \mathrm{~nm}$ bandpass for calcein and $590 \mathrm{~nm}$ longpass for ethidium homodimer, respectively). Live cells were distinguished by the presence of intracellular esterase activity, determined by enzymatic conversion of nonfluorescent calcein AM to green fluorescent calcein, whereas dead cells with damaged membranes were entered by ethidium homodimer, leading to red fluorescence after binding to nucleic acids. Viable cells are expressed as percentage of total cell number in a given area.

\section{Cell Volume Measurements}

Cell volume was measured in 30 -sec intervals using a Casy- 1 model TT (Schärfe, Reutlingen, Germany). The measurements were made after splitting the cells and growing the single cells for 12,24 , and $34 \mathrm{hr}$ in the incubator. Cell volume was calculated from the median of the cell volume distribution curves using latex beads as calibration standards $(12,13)$. During measurement cells were kept at $30-37^{\circ} \mathrm{C}$. The isotonic extracellular solution for volume measurements was (in $\mathrm{mM}$ ): $\mathrm{NaCl} 90$, mannitol 80, $\mathrm{KCl} 5.4, \mathrm{MgCl}_{2}$ $0.8, \mathrm{CaCl}_{2}$ 1.2, glucose 5.5, tris(hydroxymethyl) aminomethane (Tris) 5, pH 7.4 (adjusted with $\mathrm{NaOH}$ ). To reduce extracellular osmolarity the isotonic solution was diluted with a solution composed as above but missing mannitol. Final osmolality of the different solutions was verified by freezing point depression.

\section{RESULTS}

\section{The Swelling-Induced Chloride Current Can Be Blocked by Nucleoside Analogs Such as AZT or Acyclovir}

A chloride current of $+97.7 \pm 11 \mathrm{pA}(+40 \mathrm{mV}$; $n=44$ ) can be measured in NIH 3T3 fibroblasts (passages 60-100) under isotonic conditions. Reducing extracellular osmolarity (omitting $50 \mathrm{mM}$ mannitol) leads to a marked increase in the current to $+1473.6 \pm 104 \mathrm{pA}(n=44)$. As shown in Fig. 1, the thymidine nucleoside analog 3'-azido3'-deoxythymidine (AZT) blocks the swellinginduced chloride current $\left(\mathrm{I}_{\mathrm{Cl}}\right)$ at a half maximal concentration $\left(\mathrm{IC}_{50}\right)$ of $\approx 20 \mu \mathrm{M}$ (Fig. $\mathrm{l}$ a and b), with the block being equally effective on both current directions (Fig. 1c) 3-4 min after adding the drug to the extracellular solution.

In addition to the electrophysiological measurements, the effect of AZT on chloride transport is also demonstrated using a fluorescence optical technique. As depicted in Fig. 1d, cells challenged with a hypotonic solution show substantial chloride permeability $\left(\mathrm{P}_{\mathrm{Cl}}\right)$ across the cell membrane (see Materials and Methods). In the presence of $\mathrm{AZT}, \mathrm{P}_{\mathrm{Cl}}$ is significantly reduced.

The antiviral drug acyclovir blocks $\mathrm{I}_{\mathrm{Cl}}$ similarly to AZT $\left(\mathrm{IC}_{50} \approx 10 \mu \mathrm{M}\right.$; Fig. 2a). In contrast, ganciclovir, a compound comprised of acyclovir and an additional hydroxymethyl group at the "sugar rudiment", has no significant effect on $\mathrm{I}_{\mathrm{Cl}}$ up to a concentration of $0.1 \mathrm{mM}$ (Fig. 2b).

\section{The Nucleoside Block Can Be Influenced by the Addition of TDP and Uridine}

In contrast to AZT, the nucleotide thymidine- $5^{\prime}$ diphosphate (TDP) is not able to block $\mathrm{I}_{\mathrm{Cl}}$ at concentrations up to $0.1 \mathrm{mM}$ (Fig. 3a). In the presence of $0.1 \mathrm{mM}$ TDP, the addition of $0.1 \mathrm{mM}$ AZT has only a minute blocking effect (Fig. 3b). After washing out TDP and AZT, however, the renewed addition of $0.1 \mathrm{mM}$ AZT alone dramatically reduces $\mathrm{I}_{\mathrm{Cl}}$ (Fig. 3b). Similar effects were obtained using uridine in combination with acyclovir. In the presence of $100 \mu \mathrm{M}$ uridine, the chloride current elicited by reducing extracellular osmolarity $\left(\mathrm{I}_{\mathrm{Cl}}\right)$ is $+1321.0 \pm 191.4 \mathrm{pA}(+40$ $\mathrm{mV} ; n=8$ ). Adding $100 \mu \mathrm{M}$ acyclovir does not significantly change the current $(+1223.2 \pm$ $252.3 \mathrm{pA} ; n=8$ ). However, omitting both uridine and acyclovir, and adding $100 \mu \mathrm{M}$ acyclovir alone leads to a substantial reduction of $\mathrm{I}_{\mathrm{Cl}}$ to $+493.9 \pm 100.7 \mathrm{pA}(n=8)$ in the same cells. Uridine, as well as TDP, prevents nucleoside an- 


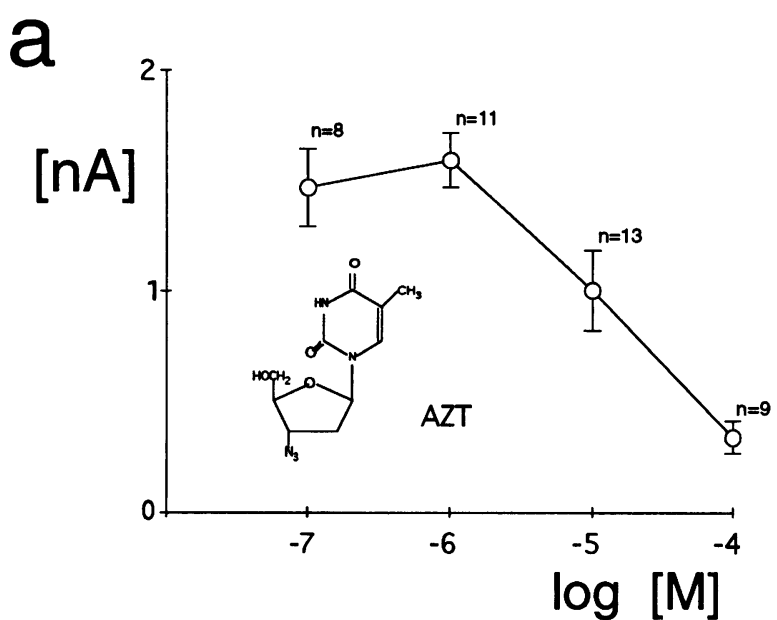

C

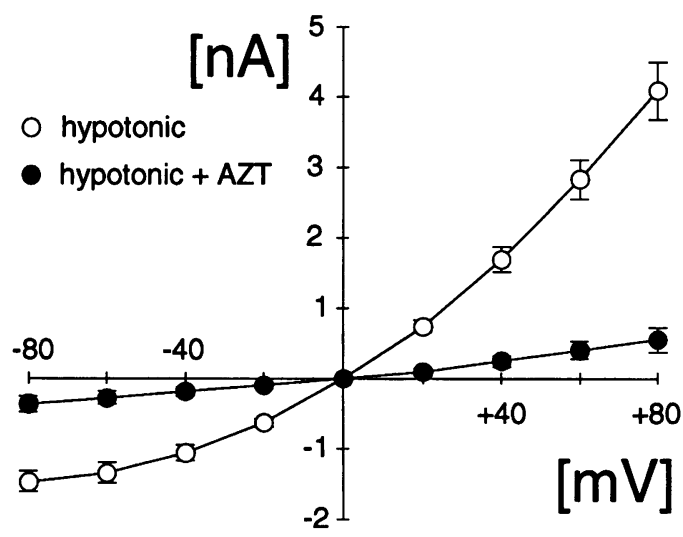

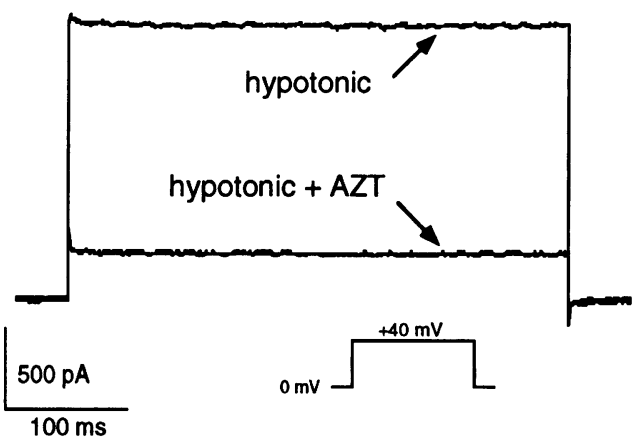

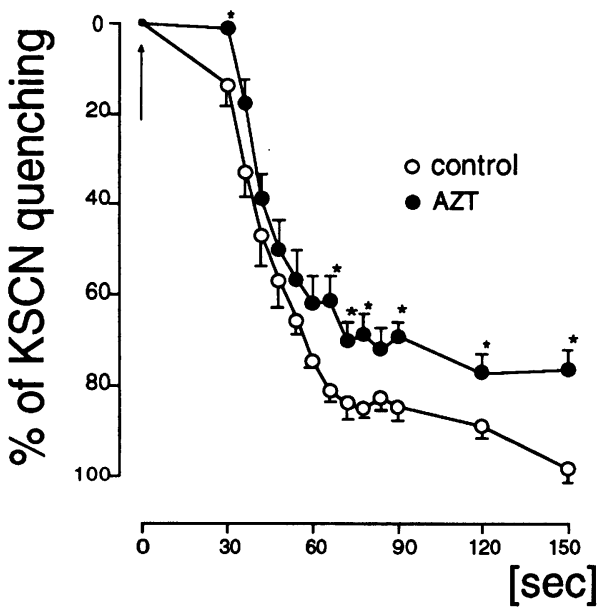

FIG. 1. Inhibition of the swelling-induced chloride current $\left(\mathrm{I}_{\mathrm{Cl}}\right)$ and chloride permeability by the antiviral drug azidothymidine (3'-azido-3'-deoxythymidine, AZT) in NIH 3T3 fibroblasts

(a) AZT blocks $\mathrm{I}_{\mathrm{Cl}}$ irreversibly. The cells were held at $0 \mathrm{mV}$ and clamped repetitively to a potential of $+40 \mathrm{mV}$ for $400 \mathrm{msec}$ (all values given without leak subtraction). Current measurements were taken 1-5 min after drug application. The insert depicts the molecular structure of the compound used. (b) Original tracing showing the inhibitory effect of $100 \mu \mathrm{M}$ AZT (hypotonic + AZT) on the swelling-induced chloride current (hypotonic) in the same NIH 3T3 fibroblast. Voltage clamp protocol as above. (c) Current voltage relation of the swelling-induced chloride current in the absence (hypotonic; open symbols) and presence of $100 \mu \mathrm{M}$ AZT (hypotonic + AZT; closed symbols). The cells were held at $0 \mathrm{mV}$ and voltage steps made for $800 \mathrm{msec}$ from $-80 \mathrm{mV}$ to $+80 \mathrm{mV}$ in $20 \mathrm{mV}$ increments. The current measurements after decreasing extracellular osmolarity are $-1466 \pm 143 \mathrm{pA},-1053 \pm 107$ $\mathrm{pA},+1692 \pm 184 \mathrm{pA}$, and $+4091 \pm 404 \mathrm{pA}$ in the absence of AZT, and $-367 \pm 111 \mathrm{pA},-185 \pm 59 \mathrm{pA},+248 \pm$ $76 \mathrm{pA}$, and $+551 \pm 170 \mathrm{pA}$ in the presence of AZT at $-80 \mathrm{mV},-40 \mathrm{mV},+40 \mathrm{mV}$, and $+80 \mathrm{mV}$, respectively (for both, $n=5$; peak current was measured $10 \mathrm{msec}$ after pulse onset). (d) Measurements of chloride permeability $\left(\mathrm{P}_{\mathrm{Cl}}\right)$ in NIH 3T3 fibroblasts in the absence (control) and presence of $100 \mu \mathrm{M}$ AZT (AZT). Independent measurements of eight cells in the absence and nine cells in the presence of AZT are summarized as total percentage of the KSCN-quenchable MEQ signal plotted for a time frame of 30-150 sec after addition of KSCN (\% KSCN quenching; see Materials and Methods). 
a

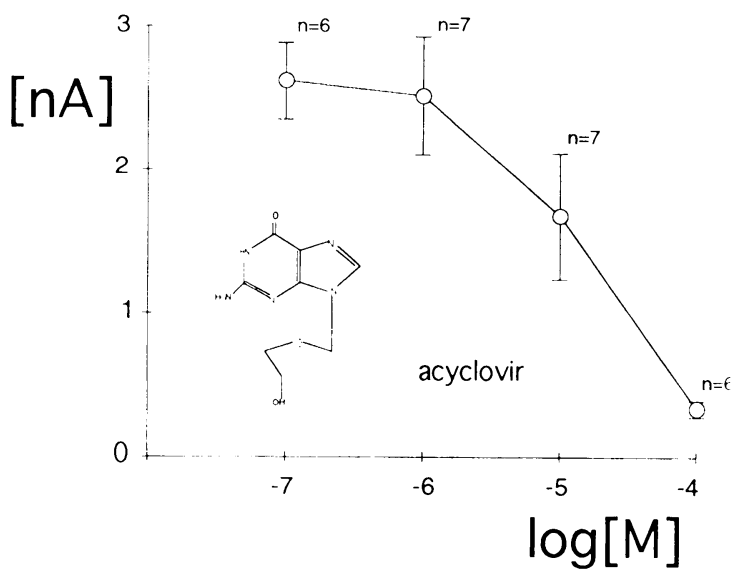

b

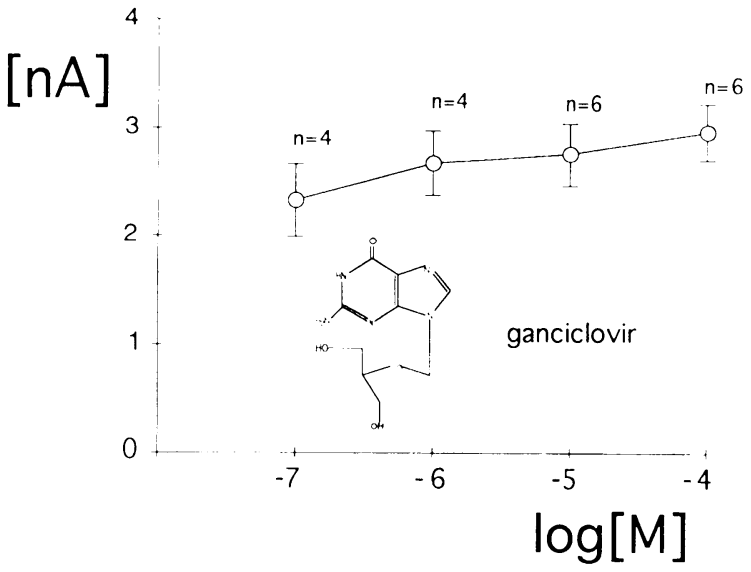

FIG. 2. Effect of acyclovir and ganciclovir on the swelling-induced chloride current in NIH 3 T3 fibroblasts

(a) Half maximal blocking effect of acyclovir is observed at a concentration of $\approx 10 \mu \mathrm{M}$. (b) Ganciclovir is without signilicant effect on $\mathrm{I}_{C 1}$ at concentrations up to $0.1 \mathrm{mM}$. The inserts depict the molecular structures of the compounds used.

alogs from blocking $\mathrm{I}_{\mathrm{C} \cdot}$, most likely by competitive binding.

The Swelling-Induced Chloride Current in T Cell Lymphoma Cells Is Sensitive to AZT and Acyclovir

Swelling-induced chloride currents sensitive to nucleotides have been shown in epithelial cells $(2-4)$, which could act as possible targets for viral
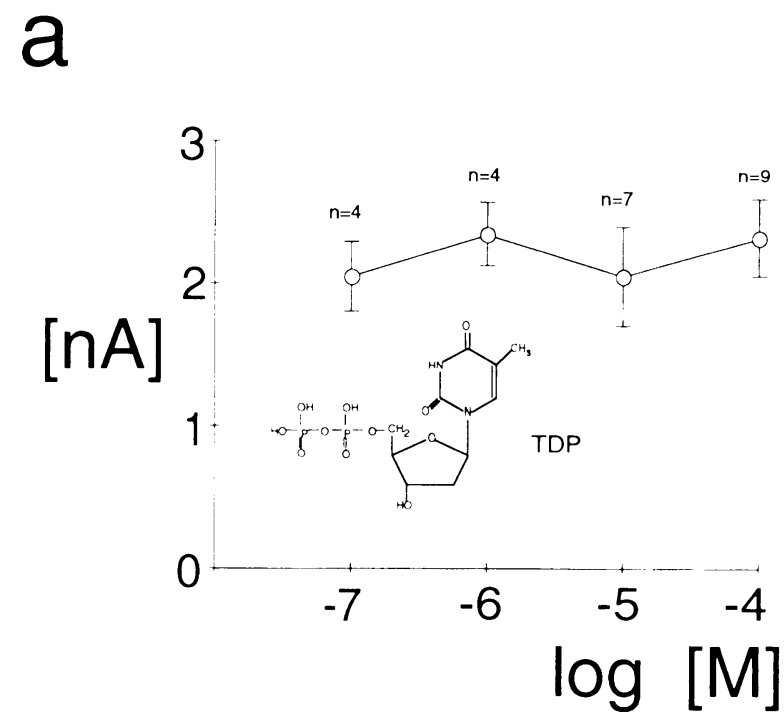

b

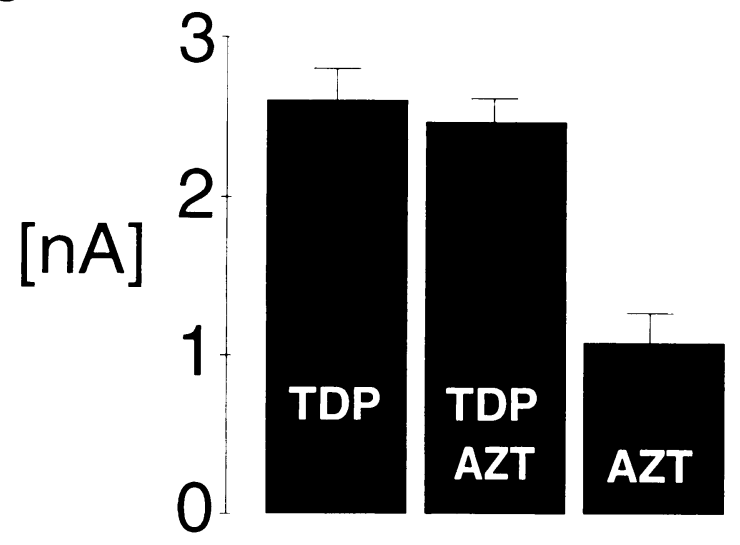

FIG. 3. The effect of thymidine 5'-diphosphate on $I_{C I}$ in NIH $3 T_{3}$ fibroblasts

(a) Thymidine 5'-diphosphate (TDP) added to the extracellular fluid is without significant effect on $I_{(: 1}$ at concentrations up to $100 \mu \mathrm{M}$ (the insert depicts the molecular structure of the compound used). (b) Addition of $100 \mu \mathrm{M}$ AZT on top of $100 \mu \mathrm{M}$ TDP only scarcely reduces $\mathrm{I}_{(;)}$. However, after washing out the TDP-AZT mixture, addition of $100 \mu \mathrm{M}$ AZT markedly reduces $I_{c: 1}(n=6)$.

infections. Since AZT is an essential drug in the treatment of human immunodeficiency virus (HIV) and T cells are the major target of HIV, we investigated whether $I_{C 1}$ sensitivity to AZT can be measured in $\mathrm{H} 9$ cells, a human $\mathrm{T}$ cell lymphoma line. The $\mathrm{I}_{\mathrm{Cl}}$ induced in $\mathrm{H} 9$ cells is as sensitive 10 AZT or acyclovir as $\mathrm{I}_{C I}$ in NIH $3 \mathrm{~T} 3$ fibroblasts ( IC $_{50}$ for $\mathrm{AZT} \approx 30 \mu \mathrm{M}$ and for acyclovir $\approx 20 \mu \mathrm{M}$; Fig. $4 \mathrm{a}$ and $\mathrm{b})$. It has been shown that $\mathrm{I}_{(\mathrm{l})}$, the swelling-induced chloride current is identical to $I_{\text {C.n }}$ or closely related to it (5). Blocking these 

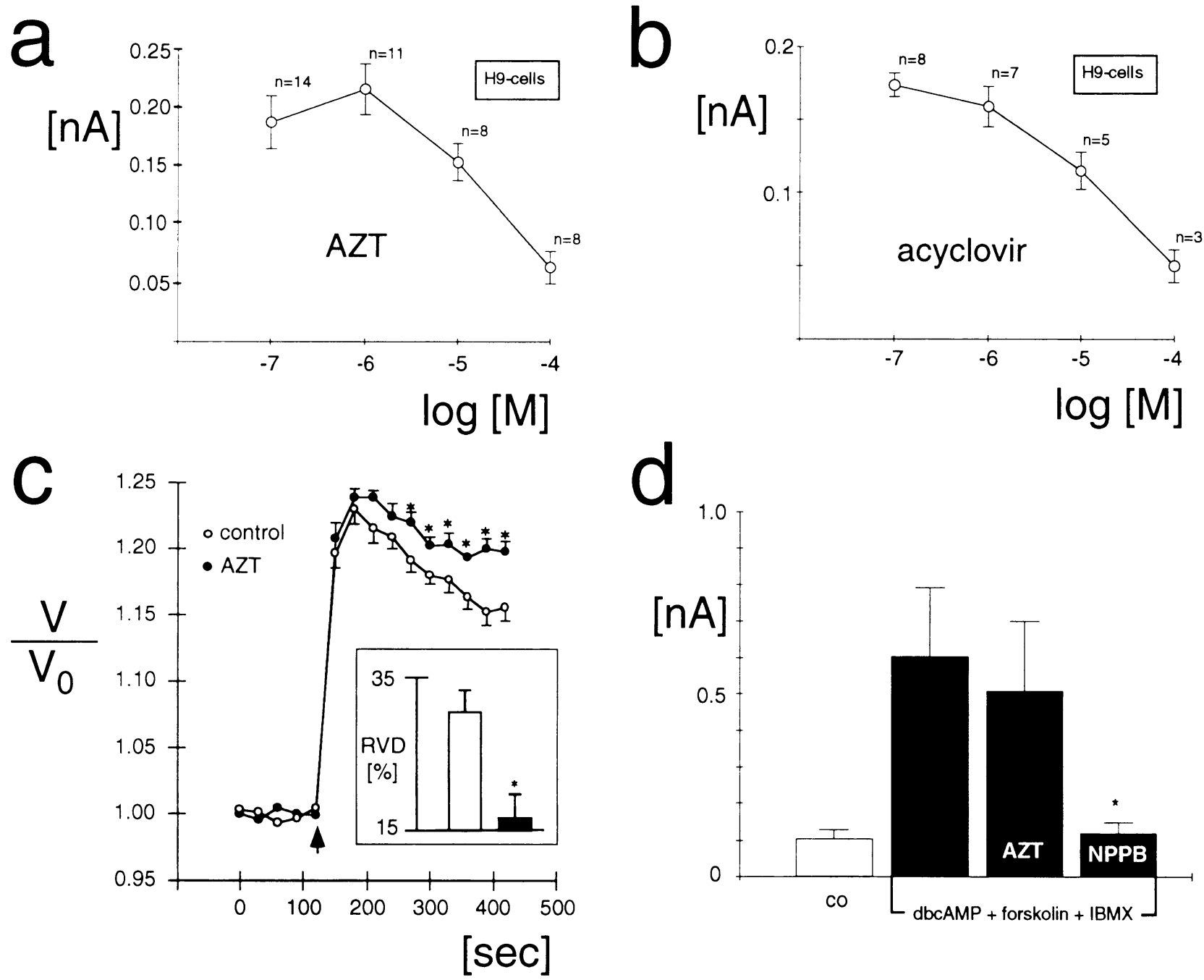

FIG. 4. AZT and acyclovir block the swelling-induced chloride current and regulatory volume decrease (RVD) in the human $\mathrm{T}$ cell lymphoma cell line $\mathbf{H} 9$

(a) In H9 cells (pulse protocol see Fig. la), half maximal blockage can be observed at a concentration of $\approx 30 \mu \mathrm{M}$ AZT added to the extracellular solution. Currents are leak subtracted. (b) Dose response curve for acyclovir added to the extracellular fluid $\left(\mathrm{IC}_{50} \approx 20 \mu \mathrm{M}\right.$ ). Currents are leak subtracted. (c) AZT significantly impedes regulatory volume decrease (RVD) in H9 cells: following reduction of extracellular osmolarity by 70 mosM H9 cells display instant cell swelling to $123.0 \pm 1.1 \%(n=8)$ in the absence (open symbols) and to $123.9 \pm 0.6 \%(n=9)$ in the presence of AZT (closed symbols). Under control conditions this cell swelling is followed by a gradual reduction of cell volume to $116.0 \pm 0.9 \%(n=6)$ within $240 \mathrm{sec}$ after peak volume. In the presence of $100 \mu \mathrm{M}$ AZT this volume decrease is diminished $10119.8 \pm 0.7 \%$. Thus RVD is significantly reduced from $30.3 \pm 3 \%$ to $16.6 \pm 3 \%$ in the presence of AZT (insert). The swelling experiments are given as actual volumes (V) divided by $V_{0}$, where $V_{0}$ is the mean of the first five measurements prior to the reduction of extracellular osmolarity versus time. RVD is expressed as loss of cell volume within $240 \mathrm{sec}$ relative to the volume gained by the cells 60 sec after imposing the osmotic gradient. (d) The sensitivity of AZT for the cAMP-activated chloride current $\left(\mathrm{I}_{\text {Clcamp }}\right)$ was measured in CaCo cells. In the presence of dbcAMP $(0.5 \mathrm{mM})$, forskolin $(0.01 \mathrm{mM})$, and $\mathrm{IBMX}(0.1 \mathrm{mM})$ a chloride current can be clicited ranging from $+102.4 \pm 60.3 \mathrm{pA}(n=5)$ to $+602.6 \pm 189.9 \mathrm{pA}(n=5)$. Extracellular AZT in a concentration of $100 \mu \mathrm{M}$ is without any significant effect on $\mathrm{I}_{\text {C.MAP }}(+508.8 \pm 191.1 \mathrm{pA} ; n=5)$. NPPB in a concentration of $0.5 \mathrm{mM}$ significantly reduces $\mathrm{I}_{\text {Cla } \mathrm{Amp}} \mathrm{to}+120.0 \pm 28.9 \mathrm{pA}(n=5)$. 
channels leads to an impaired ability of cells to regulate their volume back to "normal" after swelling [regulatory volume decrease (RVD) $(8,12)$ ]. Accordingly, as shown in Fig. 4c the addition of $100 \mu \mathrm{M}$ AZT to H9 cells dramatically reduces RVD from $30.3 \pm 2.6 \%(n=6)$ to $16.6 \pm 2.3 \%(n=9)$.

\section{AZT Does Not Block the cAMP- Dependent Chloride Current in CaCo Cells}

Blockers known to impede chloride channels poorly discriminate between the different chloride channel families (8). For better understanding of the effect of AZT on different cell systems it is essential to know if other chloride channels beside the swelling-dependent one can be blocked by this drug. To test whether cAMPdependent chloride current is sensitive to AZT applied to the extracellular solution, we activated this current in colon carcinoma $(\mathrm{CaCo})$ cells by adding a mixture of dibutyryl-cAMP $(0.5$ $\mathrm{mM})$, forskolin $(0.01 \mathrm{mM})$, and IBMX $(0.1 \mathrm{mM})$ to the extracellular solution. The experiments are summarized in Fig. 4d. Two to three minutes after the addition of the mixture, a cAMP-stimulated chloride current is elicited in these cells. The cAMP-dependent chloride current cannot be changed significantly by the addition of $100 \mu \mathrm{M}$ AZT. Replacing AZT with $0.5 \mathrm{mM}$ NPPB, a known blocker of chloride currents (14), however, dramatically reduces the current to similar values to those prior to stimulation (Fig. 4d).

\section{Volume Measurements in Fibroblasts Treated with AZT and/or HSV}

As discussed above, AZT substantially reduces RVD in $\mathrm{H} 9$ cells. $\mathrm{I}_{\mathrm{Cl}}$ is crucial for controlling the cell volume and reducing the cytoplasmatic volume after swelling. Since the resting volume of cells is lower than the equilibrium (15), blocking $\mathrm{I}_{\mathrm{Cl}}$ in resting cells should increase their volume. Also, this swelling effect of substances able to block $\mathrm{I}_{\mathrm{Cl}}$ could be intensified in virus-infected cells, which are known to show cytoplasmatic swelling after infection with a variety of different viruses $(16-23)$. To test for this effect of AZT in either uninfected fibroblasts or fibroblasts infected with herpes simplex virus (HSV), cell volumes were determined under the different experimental conditions. The absolute cell volume of fibroblasts was measured 12, 24, and $34 \mathrm{hr}$ after reculture (see Materials and Methods). In untreated cells (control in Fig. 5), the cytoplas-

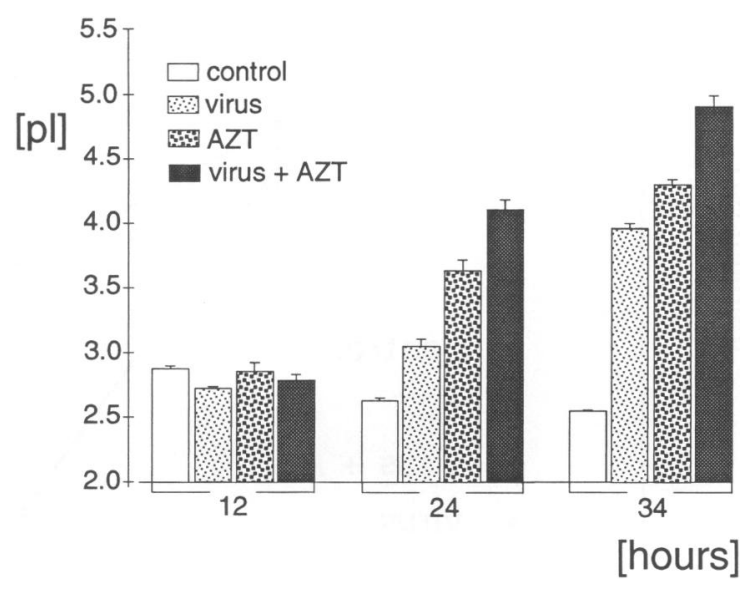

FIG. 5. Cell volume measurements in NIH $3 T_{3}$ fibroblasts in the presence and absence of AZT and in fibroblasts infected with HSV in the presence and absence of AZT

The absolute cell volumes (in pl) were measured 12, 24 , and $34 \mathrm{hr}$ after reculturing the cells. Conditions were changed immediately before the time point of $12 \mathrm{hr}$. At this point cells were exposed to AZT, virus (HSV at an m.o.i. of $>10$ ) or both. For controls the cell volumes of untreated cells were measured at the equivalent time points.

matic volume of single cells diminished from $2874 \pm 25 \mathrm{fl}(n=3)$ to $2628 \pm 19 \mathrm{fl}(n=4)$ and $2548 \pm 10 \mathrm{fl}(n=4)$ at the time points measured. Twelve hours after reculturing the cells, AZT, AZT and HSV, or HSV alone, were added to the cells and their volume determined immediately, then 12, and $22 \mathrm{hr}$ after incubation. Fibroblasts infected with HSV (HSV strain wal, [24]) at a multiplicity of infection (m.o.i.) of $>10$ (Fig. 5) increase their volume from $2725 \pm 8 \mathrm{fl}$ immediately after adding the virus, to $3050 \pm 56 \mathrm{fl}$ and $3955 \pm 46 \mathrm{fl}$ (SEM; $n=4)$. HSV strain wal was chosen for its ability to infect fibroblasts with high efficiency $(>95 \%)$, which is mandatory for the volume measurements. The addition of AZT alone increases the cell volume even further than virus infection alone. Twelve and twentytwo hours after adding the drug, the volume of the cells was $3631 \pm 84$ and $4301 \pm 38 \mathrm{fl}(n=4)$. Infection of the cells in the presence of AZT leads to a significantly larger increase in volume (4107 \pm 73 and $4912 \pm 83$ fl, $n=4$; Fig. 5).

\section{Viability Measurements of Virus-Infected Fibroblasts}

The dramatic increase of the volume of virusinfected cells in the presence of AZT might sug- 


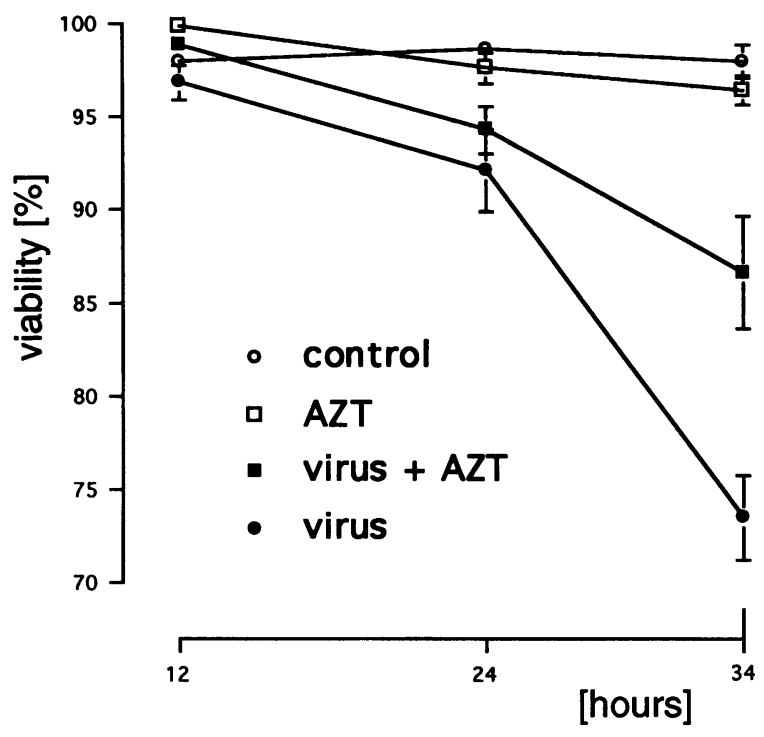

FIG. 6. Viability measurements of NIH 3 T3 fibroblasts under control conditions (open symbols) and NIH 3T3 fibroblasts infected by HSV (filled symbols) in the absence and presence of AZT

Cell viability 12,24 , and $34 \mathrm{hr}$ after splitting is expressed as percentage of total cell number in a given area.

gest a reduced viability of these cells, leading to impaired virus replication. To test for this hypothesis, the viability of fibroblasts was measured at the same time points used for volume measurements. As shown in Fig. 6, cell viability in the presence of $100 \mu \mathrm{M} \mathrm{AZT}$ is indistinguishable from that measured in the untreated cell population. The infection of fibroblasts with the HSV strain wal at a m.o.i. of $>10$ dramatically reduces the viability from $96.4 \pm 1 \%$ to $73.5 \pm$ $2 \%$ after $22 \mathrm{hr}$ of virus infection. After the same period of infection, viability is significantly higher $(86.7 \pm 3 \%)$ in the presence of AZT. The results indicate that the increased cytoplasmatic volume of virus-infected cells in the presence of AZT is not accompanied by reduced viability of the infected cells within the time measured. We cannot rule out, however, that the increased cytoplasmatic volume in virus-infected cells negatively affects virus replication.

\section{DISCUSSION}

Decreasing extracellular osmolarity leads to the activation of an outwardly rectifying chloride current, $\mathrm{I}_{\mathrm{C}}$, in NIH $3 \mathrm{~T} 3$ fibroblasts. In $\mathrm{H} 9$ cells, a similar current can be elicited with properties identical to those of $\mathrm{I}_{\mathrm{Cl}}$ in fibroblasts. Antisense oligonucleotides complementary to $\mathrm{I}_{\mathrm{Cln}}$, a cloned chloride channel from MDCK cells (1) reduces $\mathrm{I}_{\mathrm{Cl}}$ in these fibroblasts (5), indicating that $\mathrm{I}_{\mathrm{Cln}}$ is the chloride channel itself or a closely related protein (25). The simplest explanation at present is that $\mathrm{I}_{\mathrm{Cln}}$ is the chloride channel itself, as previously described $(5,8)$. However, a more complex interaction between $\mathrm{I}_{\mathrm{Cln}}$ and pre-existing proteins cannot be ruled out. A unique feature of the swelling-induced chloride current is its sensitivity to different nucleotides. $\mathrm{I}_{\mathrm{Cln}}$ expressed in $\mathrm{Xe}$ nopus oocytes can be blocked by the extracellular addition of CGMP, ITP, CAMP, GTP, ATP, ADP, or AMP (1). $\mathrm{I}_{\mathrm{Cl}}$ activated in fibroblasts can be blocked by cAMP, ATP, or CGMP (5). The molecular structures of AZT or acyclovir used in therapy of viral infections are closely related to the nucleotides tested. As we show here, both AZT and acyclovir are able to dramatically and instantaneously impede $\mathrm{I}_{\mathrm{Cl}}$ in fibroblasts and $\mathrm{H} 9$ cells, indicating that the observed inhibition of $\mathrm{I}_{\mathrm{Cl}}$ reflects a direct effect on the channels. This effect is most likely not related to premature chain termination and the consecutive indirect inhibition of $\mathrm{I}_{\mathrm{Cl}}$. The inhibition of $\mathrm{I}_{\mathrm{Cl}}$ is observed at concentrations typically present in the plasma of patients treated with these drugs (26) (Figs. 1, 2, and 4). Accordingly, fluorescence optical measurements show a significant inhibition of the KSCN quench of the MEQ fluorescence expressing chloride movement across the cell membrane (Fig. ld). AZT is able to discriminate between the swelling-dependent chloride current $\mathrm{I}_{\mathrm{Cl}}$ and the chloride current activated by cAMP (Fig. 4d) leading to a selective blockage of $\mathrm{I}_{\mathrm{Cl}}$. Moreover, we show that AZT increases the cell volume of fibroblasts (Fig. 5). These findings support our hypothesis that $\mathrm{I}_{\mathrm{Cln}}$ is the swelling-induced chloride current and that AZT and acyclovir specifically block this current.

Ganciclovir, however, does not have any significant effect on $I_{C l}$ at concentrations up to $0.1 \mathrm{mM}$. This drug, used in patients infected with cytomegalovirus, differs from acyclovir only by the addition of a hydroxymethyl group at the sugar rudiment of the acyclovir molecule (Fig. 2 $a$ and $b)$.

TDP, structurally related to AZT, is also unable to block $\mathrm{I}_{\mathrm{Cl}}$ at concentrations of up to 0.1 $\mathrm{mM}$ (Fig. 3a). It is, however, important that TDP is able to competitively inhibit the blocking effect of AZT on $\mathrm{I}_{\mathrm{Cl}}$. As shown in Fig. 3b, the addition of $100 \mu \mathrm{M}$ TDP does not impair the swelling- 
induced chloride current. In the presence of TDP, addition of AZT to the extracellular fluid has virtually no effect. However, after washing out both substances and adding $100 \mu \mathrm{M} \mathrm{AZT}, \mathrm{I}_{\mathrm{Cl}}$ is substantially reduced (Fig. $3 \mathrm{~b}$ ). Similar results can be obtained for uridine and acyclovir in NIH 3T3 fibroblasts. It has been shown that the nucleoside uridine is able to reduce the cytotoxic effect of AZT in human bone marrow progenitor cells (27), as well as the neurotoxic effect of the nucleotide ddC $\left(2^{\prime}, 3^{\prime}\right.$-dideoxycytidine) (28). Our results could provide a molecular mechanism explaining these therapeutically very important findings. In general, growing cells, neurons (and/or their surrounding glial cells), and cells with a large substrate transport and therefore high volume stress (e.g., epithelial cells in the gastrointestinal tract or tubular cells in the kidney) need powerful mechanisms to regulate their cytoplasmatic volume (15). Impairing the swelling-induced chloride current leads to a reduced regulatory volume decrease, cell swelling and, as a result, impaired organ function (15). The cytotoxic effects observed in patients treated with antiviral drugs from the nucleoside analog family are mainly restrained to bone marrow, gastrointestinal, kidney, and neuronal functions. The side effects of these drugs could be due to a block of the swelling-induced chloride current. It can be speculated that the simultaneous administration of TDP or uridine, as nonactive molecules able to bind to the chloride channel, together with AZT or acyclovir, could reduce the side effects provoked by these antiviral drugs. Additional substances, which could substitute for TDP or uridine in protecting $\mathrm{I}_{\mathrm{Cl}}$ more efficiently, are currently under investigation. Moreover, a substantial increase of the dosage of antiviral drugs of the nucleoside analog family could be feasible in conjunction with such competitive inhibitors. The role of cell swelling in virus replication is, however, still unclear. The viability of virus-infected cells, additionally swollen in the presence of AZT (Fig. 5), is not reduced when compared with that of cells infected with virus alone (Fig. 6). A direct influence of blocking RVD on virus replication by reducing viability of infected cells can be ruled out. It remains, however, to be tested if and how swelling itself affects virus replication. Such an effect could be mediated by a change in the "internal milieu" observed after cell swelling. Intracellular ions like potassium and chloride, and the intracellular $\mathrm{pH}$, are reduced under this condition $(29,30)$. In addition, the intracellular bioactive calcium con- centration (Ref. 31 and our own unpublished results) is increased in swollen cells, changing different biochemical pathways $(32,33)$. Additional experiments need to be done to determine if cell swelling could lead to a modulation of the specific sensitivity of different viruses for certain antiviral drugs.

In conclusion, our experiments show a novel molecular mechanism by which antiviral drugs of the nucleoside analog family could lead to impairments of the kidney, bone marrow, gastrointestinal, and neuronal functions, and how these side effects could possibly be restricted by the presence of TDP or uridine as competitive inhibitors for $\mathrm{I}_{\mathrm{Cl}}$ blockage.

\section{ACKNOWLEDGMENTS}

We thank Profs. R. Greger, J. Frick, and F. Lang for their helpful discussion and critical reading of the manuscript or continuous support. Mag. Gabriele Buemberger, Andrew Dobson, and Dr. Anton Hittmaier are gratefully acknowledged for their excellent technical assistance. This work was supported in part by grants from the Austrian Science Foundation (P09668 and P10393), the Union Bank of Switzerland, the Austrian National Bank, and the Rockefeller Foundation to MP.

\section{REFERENCES}

1. Paulmichl M, Li Y, Wickman K, Ackerman M, Peralta E, Clapham D. (1992) New mammalian chloride channel identified by expression cloning. Nature 356: 238-24l.

2. Alton EWFW, Manning SD, Schlatter PJ, Geddes DM, Williams AJ. (1991) Characterization of a $\mathrm{Ca}^{2+}$-dependent anion channel from sheep tracheal epithelium incorporated into planar bilayers. J. Physiol. 443: 137-159.

3. Vanglarik CJ, Singh AK, Wang R, Bridges RJ. (1993) Trinitrophenyl-ATP blocks colonic $\mathrm{Cl}^{-}$channels in planar phospholipid bilayers. Evidence for two nucleotide binding sites. J. Gen. Physiol. 101: 545-569.

4. Zhang J, Smith T, Lobaugh L, Hall S, Lieberman M. (1992) Cyclic AMP inhibits the swelling activated $\mathrm{ICl}$ associated with cardiac cell volume regulation. Physiologist 35: 18. Abstract.

5. Gschwentner M, Nagl UO, Wöll E, Schmarda A, Ritter M, Paulmichl M. (in press) Anti- 
sense oligonucleotides suppress cell volumeinduced activation of chloride channels. Pflügers Arch.

6. Marty A, Neher E. (1983) Tight-seal wholecell recording. In: Sakmann B, Neher E (eds). Single-Channel Recording. Plenum Press, New York, pp. 107-122.

7. Bubien JK, Kirk KL, Rado A, Frizzell RA. (1990) Cell cycle dependence of chloride permeability in normal and cystic fibrosis lymphocytes. Science 248: 1416-1419.

8. Paulmichl M, Gschwentner M, Wöll E, et al. (1993) Insight into the structure-function relation of chloride channels. Cell Physiol. Biochem. 3: 374-387.

9. Paulmichl M, Lang F. (1988) Enhancement of intracellular calcium concentration by extracellular ATP and UTP in Madin Darby canine kidney cells. Biochem. Biophys. Res. Commun. 156: 1139-1143.

10. Biwersi J, Verkman AS. (1991) Cell-permeable fluorescent indicator for cytosolic chloride. J. Biochem. 30: 7879-7883.

11. Kroesen BJ, Mesander G, ter Haar JG, The TH, de Leij L. (1992) Direct visualization and quantification of cellular cytotoxicity using two colour fluorescence. J. Immunol. Methods 156: 47-54.

12. Paulmichl $\mathrm{M}$, Friedrich $\mathrm{F}$, Maly $\mathrm{K}$, Lang F. (1989) The effect of hypoosmolarity on the electrical properties of Madin Darby canine kidney cells. Pflügers Arch. 413: 456-462.

13. Ritter M, Steidl M, Lang F. (1991) Inhibition of ion conductances by osmotic shrinkage of Madin-Darby canine kidney cells. Am. J. Physiol. 261: C602-C607.

14. Wangemann $P$, Wittner $M$, Di Stefano A, et al. (1986) $\mathrm{Cl}^{-}$-channel blockers in the thick ascending limb of the loop of Henle. Structure activity relationship. Pflügers Arch. 407: S128-S141.

15. Lang F, Ritter $M$, Völkl H, Häussinger D. (1993) The biological significance of cell volume. Renal Physiol. Biochem. 16: 48-65.

16. Abdul-Aziz TA, Arp LH. (1983) Progression of tracheal lesions in turkeys exposed by aerosol to LaSota strain of Newcastle disease virus. Avian Dis. 27: 1131-1141.

17. Bardadin KA, Scheuer PJ. (1984) Endothelial cell changes in acute hepatitis. A light and electron microscopic study. J. Pathol. 144: 213-220.

18. Bashford CL, Micklem KJ, Pasternak CA. (1985) Sequential onset of permeability changes in mouse ascites cells induced by
Sendai virus. Biochim. Biophys. Acta. 814: 247-255.

19. Karayiannis P, Petrovic LM, Fry M, et al. (1989) Studies of GB hepatitis agent in tamarins. Hepatology 9: 186-192.

20. McNutt NS, Kindel S, Lugo J. (1992) Cutaneous manifestations in measles in AIDS. $J$. Cutaneous Pathol. 19: 315-324.

21. Nagra RM, Burrola PG, Wiley CA. (1992) Development of spongiform encephalopathy in retroviral infected mice. Lab. Invest. 66: 292-302.

22. Neser JA, Phillips T, Thomson GR, Gainaru MD, Coetzee T. (1986) African swine fever. I. Morphological changes and virus replication in blood platelets of pigs infected with virulent haemadsorbing and non-haemadsorbing isolates. Onderstepoort J. Vet. Res. 53: 133-141.

23. Pohlenz JF, Cheville NF, Woode GN, Mokresh AH. (1984) Cellular lesions in intestinal mucosa of gnotobiotic calves experimentally infected with a new unclassified bovine virus (Breda virus). Vet. Pathol. 21: 407-417.

24. Schröder C, Engler H, Kirchner HJ. (1981) Protection of mice by an apathogenic strain of HSV-l against lethal infection by a pathogenic strain of HSV type 1. J. Gen. Virol. 52: 159-161.

25. Krapivinsky GB, Ackerman MJ, Gordon EA, Krapivinsky LD, Clapham DE. (1994) Molecular characterization of a swelling-induced chloride conductance regulatory protein, $\mathrm{p}_{\mathrm{CIn}}$. Cell 76: 439-448.

26. Jacobson MA. (1993) Valaciclovir (BW256U87): The L-valyl ester of acyclovir. J. Med. Virol. 1: 150-153.

27. Sommadossi JP, Carlisle R, Schinazi RF, Zhou Z. (1988) Uridine reverses the toxicity of $3^{\prime}$-azido-3'-deoxythymidine in normal human granulocyte-macrophage progenitor cells in vitro without impairment of antiretroviral activity. Antimicrob. Agents Chemother. 32: 997-1001.

28. Keilbaugh SA, Hobbs GA, Simpson MV. (1993) Anti-human immunodeficiency virus type 1 therapy and peripheral neuropathy: Prevention of $2^{\prime}, 3^{\prime}$-dideoxycytidine toxicity in PC12 cells, a neuronal model, by uridine and pyruvate. Mol. Pharmacol. 44: 702-706.

29. Lang F, Völkl H, Häussinger D. (1990) General principles in cell volume regulation. Comp. Physiol. 4: 1-25.

30. Ritter M, Paulmichl M, Lang F. (1991) Fur- 
ther characterization of volume regulatory decrease in cultured renal epitheloid (MDCK) cells. Pflügers Arch. 418: 35-39.

31. Pierce SK, Politis AD. (1990) $\mathrm{Ca}^{2+}$-activated cell volume recovery mechanisms. Annu. Rev. Physiol. 52: 27-42.

32. Häussinger D, Lang F. (1991) The mutual interaction between cell volume and cell function: A new principle of metabolic regulation. Biochem. Cell Biol. 69: 1-4.

33. Häussinger D, Lang F. (1991) Cell volume-A 'second messenger' in the regulation of metabolism by amino acids and hormones. Cell Physiol. Biochem. 1: 121-130.

Contributed by K. S. Warren on March 13, 1995. 